\title{
The P/S Ratio of Dietary Fats and Lipid Metabolism in Rats: Gamma-linolenic Acid as a Source of Polyunsaturated Fatty Acid
}

\author{
Joon Ho LEe, Shihomi TaguChI, Ikuo IkEDa \\ and Michihiro SUGANo* \\ Laboratory of Nutrition Chemistry, Kyushu University, \\ School of Agriculture, 46-09, Fukuoka 812, Japan \\ Received July 13, 1988
}

\begin{abstract}
The effects of different dietary levels of gamma-linolenic acid (GLA) on lipid metabolism was studied in rats using a combination of evening primrose oil (EPO) and palm oil (PLO). EPO compared to PLO significantly reduced liver cholesterol and triglyceride after 4 weeks of feeding, and the effect remained even when EPO was mixed with PLO at the same weight basis. The serum triglyceride level also tended to be low on feeding EPO. Neither liver $\triangle 6$-desaturase and phospholipase $\mathrm{A}_{2}$ activities nor aortic production of prostacyclin and thromboxane $\mathrm{A}_{2}$ production by platelets were influenced significantly by the fat type, suggesting a peculiar effect of PLO. The percentage of arachidonic acid in liver, serum, and aortic phosphatidylcholine depended on the dietary level of GLA. A more distinct increase in arachidonic acid was observed in tissue triglycerides of rats fed EPO. GLA appears to exert favorable effects on lipid metabolism even when the P/S ratio was lowered from 13.7 of EPO to 1.8 of the $1: 1$ mixture of EPO and PLO.
\end{abstract}

Gamma-linolenic acid (GLA) is more effective than linoleic acid in lowering serum cholesterol levels. ${ }^{1}$ 7) The effect of GLA, compared with linoleic acid, can in part be attributed to its prompt conversion to dihomo-GLA and then arachidonic acid, both precursors of eicosanoids, because GLA bypasses the $46-$ desaturase reaction which is the rate-limiting step in metabolism of linoleate and because some prostaglandins are possible candidates for the regulation of cholesterol metabolism. ${ }^{8 \sim 10)}$ Horrobin and $\mathrm{Huang}^{7)}$ wrote that prostacyclin and prostaglandin $\mathrm{E}_{1}$ interfere not only with smooth muscle proliferation but also with aortic accumulation of cholesterol. Hassam $^{11)}$ indicated that GLA has $15 \%$ higher biopotency as an essential fatty acid than linoleic acid. In addition, since the $\Delta 6$-desaturase activity is relatively low in humans, dietary supplementation of GLA should be appropriate, particularly in several situations where the desaturase activity is suppressed, as in the aged or in diseases such as diabetes or atherosclerosis. ${ }^{7,11)}$ Thus the use of oils containing GLA seems rational in improving disorders in lipid metabolism.

We have previously reported on the influence of the $\mathrm{P} / \mathrm{S}$ and $\omega 6 / \omega 3$ ratios of dietary fats on lipid metabolism using various combinations of fats rich in linoleate or $\alpha$-linolenate with saturated fat, and suggested the existence of an optimal situation in these variables regarding lipid parameters. ${ }^{12)}$ Since GLA appears to have a more potent activity than linoleic acid in respect to the blood and liver cholesterol levels, in this communication we studied the effects of GLA on various lipid parameters in rats using a combination of evening primrose oil and palm oil.

\section{MATERIALS AND METHODS}

Animals and diets. Four-week-old specific-pathogen-free male Sprague-Dawley rats (Seiwa Experimental Animals

* To whom requests for reprints should be addressed. 
Co., Fukuoka) were divided into three groups ( 8 rats each) according to the source of dietary fats; evening primrose oil (EPO), palm oil (PLO), and the same weight mixture of these two oils. EPO was the product of Efamol Ltd., England (kindly provided by Eisai Co., Tokyo), and PLO was from Fuji Oil Co., Osaka. The composition of the $\operatorname{diet}^{13)}$ was in weight percent; casein 20 , fat 10 , vitamin mixture (AIN-TM ${ }^{76}$ ) 1.0, mineral mixture (AIN-TM ${ }^{76}$ ) 3.5, choline bitartrate 0.2 , DL-methionine 0.3 , cellulose powder 5 , corn starch 15 , and sucrose 45 . The fatty acid composition of dietary fats is shown in Table I. Animals were housed individually in an air-conditioned room $\left(20 \sim 23^{\circ} \mathrm{C}\right.$, lights on 08:00 to $\left.20: 00 \mathrm{hr}\right)$ and fed experimental diets ad libitum for 4 weeks. Food intake and body weight were recorded every other day. The animals were killed by withdrawing blood from the abdominal aorta under light ether anesthesia. A sample of blood was clotted by incubating at $37^{\circ} \mathrm{C}$ for $30 \mathrm{~min}$ for the production of thromboxane $\mathrm{A}_{2}$ (TXA $)$ by platelets. ${ }^{14)}$ The remaining portion of blood was clotted in ice and serum was harvested. The aorta, liver, and epididymal adipose tissue were excised.

Lipid analyses. Liver and serum cholesterol, triglyceride, and phospholipid were measured as described previously. ${ }^{15)}$ Phospholipid and triglyceride were separated by thin-layer chromatography (TLC) and their fatty acid compositions were analyzed by gas-liquid chromatography on a DEGS column. ${ }^{16)}$ Cholesterol in microsomes was assayed by the cholesterol oxidase method. ${ }^{17)}$

Enzyme activities. The 46 -desaturase ${ }^{18)}$ and phospholipase $\mathrm{A}_{2}{ }^{19)}$ activities were assayed in liver microsomes using $\left[1-{ }^{14} \mathrm{C}\right]$ linoleic acid (Amersham International plc, Buckinghamshire, $59 \mathrm{mCi} / \mathrm{mmol}$ ) and 1-palmitoyl-2-[1${ }^{14}$ Cllinoleoyl-sn-3-phosphatidylethanolamine (Amersham International plc, $57 \mathrm{mCi} / \mathrm{mmol}$ ) as substrates, respectively. The activities of these enzymes were expressed as pmol of products per min per mg protein. ${ }^{12)}$ Microsomal protein was measured by the method of Lowry et al. ${ }^{20)}$

Measurement of eicosanoids. Preincubated serum was

Table I. Fatty Acid Composition of DIETARY FATS

\begin{tabular}{lcccccccc}
\hline & \multicolumn{7}{c}{ Fatty acids (weight \%) } \\
$\begin{array}{l}\text { Dietary } \\
\text { fats }\end{array}$ & $14: 0$ & $16: 0$ & $18: 0$ & $18: 1$ & $\begin{array}{r}18: 2 \\
(\omega 6)\end{array}$ & $\begin{array}{c}18: 3 \\
(\omega 6)\end{array}$ & $\begin{array}{c}\text { P/S } \\
\text { ratio }\end{array}$ \\
\hline EPO & 0.1 & 6.0 & 1.8 & 8.5 & 73.8 & 9.4 & 13.7 \\
EPO+PLO (1:1) & & & & & & \\
& 0.6 & 26.0 & 2.3 & 23.8 & 41.5 & 5.2 & 1.8 \\
PLO & 1.1 & 44.9 & 3.2 & 39.0 & 10.0 & - & 0.3 \\
\hline
\end{tabular}

EPO, evening primrose oil; PLO, palm oil. diluted twenty times with $50 \mathrm{~mm}$ phosphate buffer, $\mathrm{pH} 7.3$, containing $0.1 \%$ gelatin and $0.01 \%$ thimersol, and used for the measurement of $\mathrm{TXB}_{2}$ by radioimmunoassay (NEK007, New England Nuclear, Boston MA). ${ }^{12,14)}$ 6-Keto$\mathrm{PGF}_{1 \alpha}$ produced during incubation of the thoracic aorta at $25^{\circ} \mathrm{C}$ for $30 \mathrm{~min}$ was extracted ${ }^{4)}$ and analyzed by radioimmunoassay (NEK-008, New England Nuclear). ${ }^{12,14)}$

Statistical analysis. Data were analyzed by a one-way analysis of variance followed by inspection of all difference between pairs of means by Duncan's multiple-range test.

\section{RESULTS}

\section{Growth performance and liver weight}

Rats weighing an average of $114 \sim 115 \mathrm{~g}$ consumed 19.5 20.4 g/day of diets and gained $209 \sim 216 \mathrm{~g}$ on average for 4 weeks. There were no significant differences in these parameters among the groups. Relative liver weight was comparable in general (average $4.38 \sim 4.76 \mathrm{~g}$ / $100 \mathrm{~g}$ body weight) although it tended to be to some extent heavier in the PLO group than in the other groups.

\section{Lipid concentrations}

As shown in Table II, concentrations of liver cholesterol and triglyceride were markedly lower in rats fed EPO than in those fed PLO. In addition, even when rats were fed a $1: 1$ mixture of these oils, the liver-lipid-lowering effect of EPO still remained. The concentration of serum cholesterol was not influenced

\section{Table II. Concentrations of SERum and LIVER LIPIDS}

\begin{tabular}{lccc}
\hline & \multicolumn{3}{c}{ Groups } \\
\cline { 2 - 4 } Lipids & EPO & EPO +PLO & PLO \\
\hline Serum (mg/dl) & & & \\
Cholesterol & $115 \pm 6$ & $115 \pm 8$ & $116 \pm 5$ \\
Phospholipid & $228 \pm 16$ & $253 \pm 16$ & $244 \pm 9$ \\
Triglyceride & $256 \pm 33$ & $307 \pm 39$ & $316 \pm 66$ \\
Liver (mg/g) & & & \\
Cholesterol & $2.54 \pm 0.16^{\mathrm{a}}$ & $2.57 \pm 0.21^{\mathrm{a}}$ & $4.90 \pm 0.56^{\mathrm{b}}$ \\
Phospholipid & $29.3 \pm 0.5$ & $29.5 \pm 0.5$ & $29.6 \pm 0.6$ \\
Triglyceride & $32.2 \pm 6.2^{\mathrm{a}}$ & $38.5 \pm 8.1^{\mathrm{a}}$ & $110 \pm 23^{\mathrm{b}}$ \\
\hline
\end{tabular}

Means \pm SE of 7 to 8 rats per group.

$\mathrm{a}, \mathrm{b}$ Values in the same line with different superseript letters denote significant difference at $p<0.01$. 
Table III. Enzyme Activities of Liver Microsomes and Eicosanoid Production

\begin{tabular}{|c|c|c|c|c|}
\hline \multirow{2}{*}{ Groups } & \multicolumn{2}{|c|}{ Enzyme activity } & \multicolumn{2}{|c|}{ Eicosanoid production } \\
\hline & \multicolumn{2}{|c|}{$(\mathrm{pmol} / \mathrm{min} \cdot \mathrm{mg}$ protein $)$} & $\begin{array}{l}\text { Prostacyclin* } \\
\text { (ng/mg aorta) }\end{array}$ & $\begin{array}{l}\text { Thromboxane } \mathrm{A}_{2}{ }^{* *} \\
\quad(\mathrm{ng} / \mathrm{ml} \text { serum })\end{array}$ \\
\hline EPO & $94.2 \pm 10.9$ & $450 \pm 37$ & $2.66 \pm 0.31$ & $527 \pm 80$ \\
\hline $\mathrm{EPO}+\mathrm{PLO}$ & $106 \pm 17$ & $442 \pm 28$ & $3.03 \pm 0.26$ & $468 \pm 87$ \\
\hline PLO & $118 \pm 22$ & $501 \pm 31$ & $2.57 \pm 0.27$ & $306 \pm 71$ \\
\hline
\end{tabular}

Means \pm SE of 6 to 8 rats per group.

*,** Measured as 6-keto-PGF ${ }_{1 \alpha}$ and thromboxane $\mathrm{B}_{2}$, respectively.

Table IV. Fatty Acid Composition of Phosphatidylcholine in Liver, Serum and Aorta

\begin{tabular}{|c|c|c|c|c|c|c|c|c|c|}
\hline \multirow{2}{*}{ Fatty acid } & \multicolumn{3}{|c|}{ Liver } & \multicolumn{3}{|c|}{ Serum } & \multicolumn{3}{|c|}{ Aorta } \\
\hline & EPO & $\begin{array}{c}\mathrm{EPO}+ \\
\mathrm{PLO}\end{array}$ & PLO & EPO & $\begin{array}{c}\mathrm{EPO}+ \\
\text { PLO }\end{array}$ & PLO & EPO & $\begin{array}{c}\mathrm{EPO}_{+} \\
\mathrm{PLO}\end{array}$ & POL \\
\hline & \multicolumn{9}{|c|}{ (Weight $\%)$} \\
\hline 14:0 & 0.2 & 0.3 & 0.3 & $0.2^{\mathrm{a}}$ & $0.3^{\mathrm{b}}$ & $0.3^{\mathrm{b}}$ & $1.0^{\mathrm{ab}}$ & $0.9^{\mathbf{a}}$ & $1.3^{\mathrm{b}}$ \\
\hline $16: 0$ & $17.7^{\mathrm{ab}}$ & $18.8^{\mathrm{a}}$ & $17.3^{b}$ & $18.8^{\mathrm{a}}$ & $21.1^{\mathrm{b}}$ & $19.3^{\mathrm{ab}}$ & 34.7 & 34.5 & 34.0 \\
\hline $16: 1$ & $0.9^{\mathrm{a}}$ & $1.3^{\mathrm{b}}$ & $1.7^{\mathrm{b}}$ & $0.8^{\mathrm{a}}$ & $1.1^{\mathrm{ab}}$ & $1.3^{\mathrm{b}}$ & $2.4^{\mathrm{a}}$ & $2.5^{\mathrm{a}}$ & $3.3^{\mathrm{b}}$ \\
\hline $18: 0$ & $22.2^{\mathrm{a}}$ & $22.5^{\mathrm{ab}}$ & $24.2^{\mathrm{b}}$ & $21.5^{\mathrm{a}}$ & $22.1^{\mathrm{ab}}$ & $23.2^{\mathrm{b}}$ & $12.6^{\mathrm{a}}$ & $12.2^{\mathrm{ab}}$ & $11.2^{\mathrm{b}}$ \\
\hline $18: 1$ & $4.3^{\mathrm{a}}$ & $6.6^{\mathrm{b}}$ & $10.5^{c}$ & $5.8^{\mathrm{a}}$ & $7.6^{\mathrm{b}}$ & $12.8^{\mathrm{c}}$ & $11.5^{\mathrm{a}}$ & $12.8^{\mathrm{b}}$ & $16.1^{\mathrm{c}}$ \\
\hline $18: 2(\omega 6)$ & $7.4^{\mathrm{a}}$ & $7.5^{\mathrm{a}}$ & $6.0^{\mathrm{b}}$ & $17.0^{\mathrm{a}}$ & $15.5^{\mathrm{a}}$ & $12.8^{\mathrm{b}}$ & $4.6^{\mathrm{a}}$ & $4.0^{\mathrm{ab}}$ & $3.4^{\mathrm{b}}$ \\
\hline $18: 3(\omega 0)$ & $0.3^{\mathrm{a}}$ & $0.3^{\mathrm{a}}$ & $0.2^{\mathrm{b}}$ & $0.5^{\mathrm{a}}$ & $0.4^{b}$ & $0.1^{\mathrm{c}}$ & $0.3^{\mathrm{a}}$ & $0.3^{\mathrm{a}}$ & $0.1^{\mathrm{b}}$ \\
\hline $18: 3(\omega 3)$ & 0.2 & 0.2 & 0.3 & 0.3 & 0.3 & 0.3 & $0.2^{\mathrm{a}}$ & $0.3^{\mathrm{a}}$ & $0.4^{\mathrm{b}}$ \\
\hline $20: 3(\omega 6)$ & $1.0^{\mathrm{a}}$ & $1.7^{\mathrm{ab}}$ & $1.9^{\mathrm{b}}$ & $0.9^{\mathrm{a}}$ & $1.4^{\mathrm{ab}}$ & $1.9^{\mathrm{b}}$ & $1.3^{a}$ & $1.1^{\mathrm{ab}}$ & $1.0^{\mathrm{b}}$ \\
\hline $20: 4(\omega 6)$ & $34.9^{\mathrm{a}}$ & $32.7^{\mathrm{a}}$ & $26.8^{b}$ & $25.3^{\mathrm{a}}$ & $23.1^{\mathrm{a}}$ & $18.4^{\mathrm{b}}$ & $22.4^{a}$ & $21.7^{\mathrm{a}}$ & $19.4^{\mathrm{b}}$ \\
\hline $22: 5(\omega 6)$ & $5.7^{\mathrm{a}}$ & $4.4^{\mathrm{b}}$ & $4.2^{b}$ & 4.5 & 3.8 & 3.5 & 1.1 & 1.2 & 1.0 \\
\hline $22: 6(\omega 3)$ & $1.3^{\mathrm{a}}$ & $1.4^{\mathrm{a}}$ & $2.2^{\mathrm{b}}$ & $0.9^{\mathrm{a}}$ & $0.9^{\mathrm{a}}$ & $1.5^{\mathrm{b}}$ & $0.7^{\mathrm{a}}$ & $0.8^{\mathrm{a}}$ & $1.0^{\mathrm{b}}$ \\
\hline $20: 4 / 18: 2$ & 4.8 & 4.4 & 4.6 & 1.5 & 1.5 & 1.5 & $5.2^{\mathrm{a}}$ & $5.8^{\mathrm{b}}$ & $5.8^{\mathrm{b}}$ \\
\hline
\end{tabular}

Means of 5 to 6 rats per group.

$a, b, c$ In each tissue, values in the same line with different superscript letters denote significant difference at $p<0.05$.

by the type of dietary fats, but serum triglyceride tended to be low in the EPO group. Dietary fat did not affect the concentration of serum and liver phospholipid. The concentration of liver microsomal cholesterol was comparable among the groups $(20.9 \pm 0.8,18.6 \pm$ 0.7 , and $20.5 \pm 0.7 \mu \mathrm{g} / \mathrm{mg}$ protein for the EPO, $\mathrm{EPO}+\mathrm{PLO}$, and PLO groups, respectively).

\section{Enzyme activities and eicosanoid productions}

There were no significant differences in 46 desaturase and phospholipase $\mathrm{A}_{2}$ activities of liver microsomes among the three groups (Table III). Aortic production of prostacyclin measured as 6-keto-PGF ${ }_{1 \alpha}$ and production of $\mathrm{TXA}_{2}$ by platelets, measured as $\mathrm{TXB}_{2}$, were not significantly different among the three groups, although the TXA 2 production tended to be lower in rats fed PLO than in those fed EPO (Table III).

\section{Fatty acid compositions of tissue lipids}

Fatty acid compositions of phosphatidylcholine (PC) in liver, serum, and aorta were in general not much different among the three groups (Table IV). However, the percentage of arachidonic acid was significantly higher in the two groups of rats fed EPO compared to those fed PLO alone and the percentage of linoleic acid was also low in the PLO group. Thus the 
ratio of $20: 4 / 18: 2$ was comparable among the three groups in the tissues examined. The fatty acid composition of liver phosphatidylethanolamine (PE) differed to some extent from that of liver PC (Table V). Since there was rather a lower level of arachidonic acid and a higher level of linoleic acid in rats fed EPO than in those fed PLO, the ratio of

Table V. Fatty Acid Composition of Phosphatidyl-ETHANOLAmine In Liver

\begin{tabular}{|c|c|c|c|}
\hline \multirow{2}{*}{ Fatty acid } & \multicolumn{3}{|c|}{ Groups } \\
\hline & EPO & $\begin{array}{c}\mathrm{EPO}+ \\
\mathrm{PLO}\end{array}$ & PLO \\
\hline & \multicolumn{3}{|c|}{ (Weight $\%$ ) } \\
\hline 14:0 & 0.2 & 0.2 & 0.3 \\
\hline $16: 0$ & 16.0 & 16.5 & 15.7 \\
\hline $16: 1$ & $0.7^{\mathrm{a}}$ & $0.8^{\mathrm{a}}$ & $1.0^{\mathrm{b}}$ \\
\hline $18: 0$ & 21.5 & 22.8 & 23.5 \\
\hline $18: 1$ & $5.1^{\mathrm{a}}$ & $5.1^{\mathrm{a}}$ & $7.4^{b}$ \\
\hline $18: 2(\omega 6)$ & $5.1^{\mathrm{a}}$ & $4.3^{\mathrm{a}}$ & $2.4^{\mathrm{b}}$ \\
\hline $18: 3(\omega 6)$ & $0.2^{\mathrm{a}}$ & $0.2^{b}$ & $0.1^{\mathrm{c}}$ \\
\hline $18: 3(\omega 3)$ & 0.2 & 0.2 & 0.3 \\
\hline $20: 3(\omega 6)$ & $0.8^{\mathrm{ab}}$ & $0.9^{\mathrm{a}}$ & $0.6^{\mathrm{b}}$ \\
\hline $20: 4(\omega 6)$ & $28.8^{\mathrm{a}}$ & $31.3^{b}$ & $31.5^{\mathrm{b}}$ \\
\hline $22: 5(\omega 6)$ & $12.5^{\mathrm{a}}$ & $9.7^{a b}$ & $8.4^{\mathrm{b}}$ \\
\hline $22: 6(\omega 3)$ & $3.2^{\mathrm{a}}$ & $3.5^{\mathrm{a}}$ & $5.3^{b}$ \\
\hline $20: 4 / 18: 2$ & $5.8^{\mathrm{a}}$ & $7.4^{\mathrm{a}}$ & $13.5^{b}$ \\
\hline
\end{tabular}

Means of 5 to 6 rats per group.

$a, b, c$ Values in the same line with different superscript letters denote significant difference at $p<0.05$.
20:4/18:2 was significantly lower in the former than in the latter in liver PE, but that of docosapentaenoic acid $(\omega 6)$ was higher in the former. The percentage of docosahexaenoic acid $(\omega 3)$ was low in rats fed EPO. Fatty acid compositions of triglyceride in liver, serum, and adipose tissue reflected those of dietary fats (Table VI). The percentage of linoleic acid and GLA depended on the dietary level and that of arachidonic acid was markedly higher in the EPO than in the PLO groups.

\section{DISCUSSION}

In this study, the hypocholesterolemic effect of EPO was not observed. This could exclusively be attributable to the use of diet free of cholesterol. However, liver cholesterol and triglyceride levels were much lower in the EPO than in the PLO groups. Even when EPO was mixed with PLO, the liver lipid-raising effect of PLO was completely suppressed. The same trend was observed by Horrobin and Huang, ${ }^{7)}$ who suggested that the reduction of liver cholesterol on feeding EPO with a diet free of cholesterol may be ascribed either to reduced cholesterol transport to the liver, enhanced cholesterol excretion, or reduced cholesterol synthesis. Because in our previous

Table VI. Fatty Acid Composition of Triglyceride in Liver, Serum and Adipose Tissue

\begin{tabular}{|c|c|c|c|c|c|c|c|c|c|}
\hline \multirow{2}{*}{ Fatty acid } & \multicolumn{3}{|c|}{ Liver } & \multicolumn{3}{|c|}{ Serum } & \multicolumn{3}{|c|}{ Adipose tissue } \\
\hline & $\mathrm{EPO}$ & $\begin{array}{c}\mathrm{EPO}+ \\
\mathrm{PLO}\end{array}$ & PLO & EPO & $\begin{array}{c}\text { EPO }+ \\
\text { PLO }\end{array}$ & PLO & EPO & $\begin{array}{c}\mathrm{EPO}+ \\
\mathrm{PLO}\end{array}$ & PLO \\
\hline & \multicolumn{9}{|c|}{ (Weight $\%$ ) } \\
\hline $14: 0$ & 1.2 & 1.4 & 1.5 & $0.5^{\mathrm{a}}$ & $0.9^{\mathrm{b}}$ & $1.0^{\mathrm{b}}$ & $1.0^{\mathrm{a}}$ & $1.2^{\mathrm{b}}$ & $1.3^{b}$ \\
\hline $16: 0$ & $32.3^{\mathrm{a}}$ & $40.8^{b}$ & $41.1^{b}$ & $17.7^{\mathrm{a}}$ & $26.4^{b}$ & $31.6^{\mathrm{c}}$ & $18.6^{\mathrm{a}}$ & $25.2^{\mathrm{b}}$ & $30.7^{\circ}$ \\
\hline $16: 1$ & $6.9^{\mathrm{a}}$ & $10.1^{b}$ & $9.5^{\mathrm{ab}}$ & $3.5^{\mathrm{a}}$ & $6.0^{\mathrm{b}}$ & $7.1^{\mathrm{b}}$ & $4.0^{\mathrm{a}}$ & $5.7^{\mathrm{a}}$ & $7.8^{\mathrm{b}}$ \\
\hline $18: 0$ & 2.2 & 2.3 & 2.3 & 2.3 & 2.0 & 2.4 & 2.6 & 2.7 & 2.5 \\
\hline $18: 1$ & $21.7^{\mathrm{a}}$ & $32.7^{\mathrm{b}}$ & $43.4^{\mathrm{c}}$ & $15.7^{\mathrm{a}}$ & $29.3^{\mathrm{b}}$ & $48.0^{\mathrm{c}}$ & $16.1^{\mathrm{a}}$ & $30.5^{b}$ & $48.3^{\mathrm{c}}$ \\
\hline $18: 2(\omega 6)$ & $28.0^{\mathrm{a}}$ & $9.9^{b}$ & $1.4^{\mathrm{c}}$ & $42.0^{\mathrm{a}}$ & $24.3^{\mathrm{b}}$ & $5.7^{\mathrm{c}}$ & $48.8^{\mathrm{a}}$ & $30.1^{\mathrm{b}}$ & $7.8^{\mathrm{c}}$ \\
\hline $18: 3(\omega) 6)$ & $1.3^{\mathrm{a}}$ & $0.5^{\mathrm{b}}$ & $0.1^{\mathrm{c}}$ & $2.9^{\mathrm{a}}$ & $1.5^{\mathrm{b}}$ & $0.2^{\mathrm{c}}$ & $3.3^{a}$ & $1.6^{\mathrm{b}}$ & $0.1^{\mathrm{c}}$ \\
\hline $18: 3(\omega 3)$ & $0.3^{\mathrm{a}}$ & $0.2^{b}$ & $0.1^{\mathrm{c}}$ & 0.6 & 0.7 & 0.8 & 0.7 & 0.7 & 0.6 \\
\hline $20: 3(\omega 6)$ & $0.7^{\mathrm{a}}$ & $0.2^{\mathrm{b}}$ & - & $1.4^{\mathrm{a}}$ & $0.9^{\mathrm{b}}$ & $0.1^{\mathrm{c}}$ & $0.7^{\mathrm{a}}$ & $0.3^{\mathrm{b}}$ & - \\
\hline $20: 4(\omega 6)$ & $2.9^{\mathrm{a}}$ & $0.7^{\mathrm{b}}$ & $0.1^{\mathrm{b}}$ & $8.1^{\mathrm{a}}$ & $4.0^{\mathrm{b}}$ & $0.6^{\mathrm{c}}$ & $2.3^{\mathrm{a}}$ & $0.8^{\mathrm{b}}$ & $0.2^{\mathrm{c}}$ \\
\hline
\end{tabular}

Means of 5 to 6 rats per group.

a,b;c In each tissue, values in the same line with different superscript letters denote significant difference at $p<0.05$. 
study $^{3)}$ EPO increased fecal excretion of neutral steroids at the initial stage, the enhanced excretion of cholesterol could not at least be ruled out. The significant increase of liver triglyceride in the PLO group is probably attributed to an enhanced production in the liver. ${ }^{21)}$ Since EPO, even when mixed with PLO, markedly reduced accumulation of liver triglyceride, GLA appears to decrease its hepatic production efficiently.

On the other hand, when the cholesterolenriched diet was fed, the cholesterol-lowering effect of EPO was more evident in plasma than in liver. ${ }^{2)}$ Thus, the mechanism of cholesterollowering action of EPO is still equivocal, although GLA seems to be an active component responsible for the hypocholesterolemic effect of linoleic acid. Takayasu et al. ${ }^{1)}$ suggested that GLA exerts the hypocholesterolemic effect after it is converted to arachidonic acid. As GLA compared with linoleic acid is more easily converted to arachidonic acid, it may be more effective than linoleic acid. Horrobin and Huang $^{7}$ stated that the lowering effect of PUFA on plasma cholesterol may in part be mediated after they were converted to prostaglandins, especially prostacyclin from arachidonic acid and prostaglandin $\mathrm{E}_{1}$ from dihomoGLA. These prostaglandins inhibit cholesterol synthesis and stimulate mobilization of cholesterol esters from cholesterol-loaded cells. ${ }^{7)}$ Thus it seems that both the non-eicosanoid and eicosanoid functions are allowable.

In our previous study, ${ }^{12)}$ the percentage of arachidonic acid in tissue PC was comparable in rats fed safflower oil and PLO despite a large difference in the linoleate level in these fats. In this study, rats fed EPO that contained a similar amount of PUFA comparing to safflower oil showed a significantly higher percentage of arachidonic acid than in those fed PLO in tissue PC. Thus, the metabolism of linoleate to arachidonate seems to be limited even in the rat model and hence, arachidonate production depends on the dietary GLA. In liver PE, although the percentage of arachidonic acid was rather lower in the EPO than in the PLO groups, the production of docosa- pentaenoic acid $(\omega 6)$ from arachidonic acid by 44-desaturase was apparently higher in the former. Consequently, the sum of these two desaturation products tended to be rather higher in rats fed EPO compared to those fed PLO, indicating an enhancement of 44 desaturation by dietary EPO.

Although EPO increased aortic arachidonate, prostacyclin production was independent of dietary fat in this study. Consistent with these observations, the activities of 46 -desaturase and phospholipase $\mathrm{A}_{2}$, both regulating enzymes in eicosanoid production, were not changed by the dietary fat-type. However we previously observed in rats that EPO increased prostacyclin production either when linoleate desaturation was restricted by dietary cholesterol, ${ }^{4,5)}$ or when hamsters, which have a limited desaturase activity, were used. ${ }^{6)}$ The $\mathrm{TXA}_{2}$ production by platelets tended to be higher in the EPO than in the PLO groups, although not significantly. When a cholesterolenriched diet was fed, the concentration of plasma $\mathrm{TXB}_{2}$ tended to be lower in rats fed EPO compared to those fed safflower oil or soybean oil, ${ }^{4)}$ and also in rats fed mold oil containing GLA than in those fed palm olein. ${ }^{5)}$ Thus, dietary cholesterol seems to act as a powerful regulating agent in eicosanoid production, including inhibition of linoleate desaturation, ${ }^{22,23)}$ and GLA appears to exert its effect clearly under this situation. The lack of definiteness in the effect of GLA on eicosanoid production in this study may in part be attributable to a peculiar effect of PLO that appears neither hypercholesterolemic, ${ }^{24)}$ nor thrombotic, ${ }^{25)}$ in spite of a high level of saturated fatty acid and a low level of linoleic acid.

This study showed that EPO reduced the liver lipid level even it was mixed with PLO at the same weight level and thus, the $\mathrm{P} / \mathrm{S}$ ratio of 1.8 was similarly effective to the ratio of 13.7 . The results of this study thus provided useful indices in establishing the appropriate $\mathrm{P} / \mathrm{S}$ ratio for desirable lipid metabolism. 


\section{REFERENCES}

I) K. Takayasu and I. Yoshikawa, Lipids, 6, 47 (1971).

2) Y. S. Huang, M. S. Manku and D. F. Horrobin, Lipids, 19, 664 (1984).

3) M. Sugano, T. Ide, T. Ishida and K. Yoshida, Ann. Nutr. Metabol., 30, 289 (1986).

4) M. Sugano, T. Ishida and T. Ide, Agric. Biol. Chem., 50, 2335 (1986)

5) M. Sugano, T. Ishida, K. Yoshida, K. Tanaka, M. Niwa, M. Arima and A. Morita, Agric. Biol. Chem., 50, 2483 (1986).

6) T. Ide, M. Sugano, T. Ishida, M. Niwa, M. Arima and A. Morita, Nutr. Res., 7, 1085 (1987).

7) D. F. Horrobin and Y. S. Huang, Int. J. Cardiology, 17, 241 (1987).

8) D. P. Hajjar, B. B. Weksler, D. J. Falcone, J. M. Hefton, K. Tack-Goldman and C. R. Minick, J. Clin. Invest., 70, 479 (1982).

9) D. P. Hajjar and B. B. Weksler, J. Lipid Res., 24, 1176 (1983).

10) D. P. Hajjar, Enzyme, 32, 218 (1984).

11) A. G. Hassam, in "The Role of Fats in Human Nutrition," ed. by F. B. Padly and J. Podmore, Ellis Horwood, Chichester, 1985, pp. 84 100.

12) J. H. Lee, M. Sugano and T. Ide, J. Nutr. Sci.
Vitaminol., 34, 117 (1988).

13) American Institute of Nutrition, Report of AIN Ad Hoc Committee on Standards for Nutritional Studies, J. Nutr., 107, 1340 (1977).

14) K. D. Croft, J. P. Codde, A. Barden, R. Vandongen and L. J. Beilin, Biochim. Biophys. Acta, 834, 316 (1985).

15) T, Nagata, K. Imaizumi and M. Sugano, Br.J. Nutr., 44, 113 (1980).

16) M. Sugano, K. Ryu and T. Ide, J. Lipid Res., 25, 474 (1985).

17) T. Ide, H. Oku and M. Sugano, Metabolism, 31, 1065 (1982).

18) L. Svensson, Lipids, 18, 171 (1983).

19) J. D. Newkirk and M. Weite, Biochim. Biophys. Acta, 298, 562 (1973).

20) O. H. Lowry, N. J. Rosebrough, A. L. Farr and R. J. Randall, J.Biol. Chem., 193, 265 (1951).

21) S. M. Grundy, Circulation, 76, 523 (1987).

22) A. I. Leikin and R. R. Brenner, Biochim. Biophys. Acta, 922, 294 (1987).

23) M. L. Garg, E. Sebokova, A. B. R. Thomson and M. T. Clandinin, Biochem. J., 249, 351 (1988).

24) P. M. Kris-Etherton, C. Y. Ho and M. A. Fosmire, J. Nutr., 114, 1675 (1984).

25) Nutr. Rev., 45, 205 (1987). 